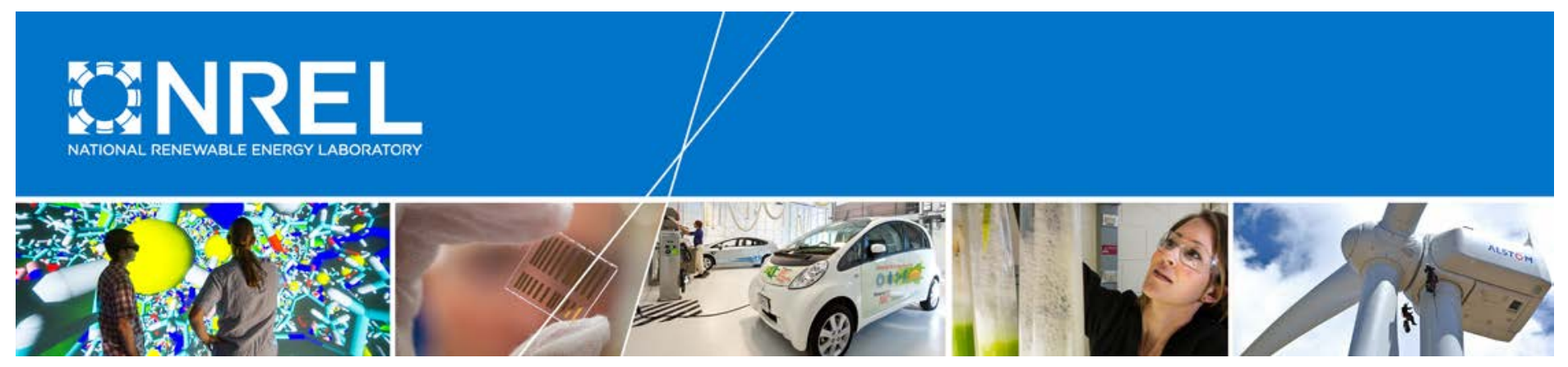

\title{
The Value of Transparency in Distributed Solar PV Markets
}

Eric O'Shaughnessy and Robert Margolis National Renewable Energy Laboratory

NREL is a national laboratory of the U.S. Department of Energy Office of Energy Efficiency \& Renewable Energy Operated by the Alliance for Sustainable Energy, LLC

This report is available at no cost from the National Renewable Energy Laboratory (NREL) at www.nrel.gov/publications.

Technical Report

NREL/TP-6A20-70095

October 2017

Contract No. DE-AC36-08GO28308 


\section{The Value of Transparency in Distributed Solar PV Markets}

\section{Eric O'Shaughnessy and Robert Margolis National Renewable Energy Laboratory}

Prepared under Task No. SETP.10306.17.01
NREL is a national laboratory of the U.S. Department of Energy Office of Energy Efficiency \& Renewable Energy Operated by the Alliance for Sustainable Energy, LLC

This report is available at no cost from the National Renewable Energy Laboratory (NREL) at www.nrel.gov/publications.

\section{Technical Report}

NREL/TP-6A20-70095

October 2017

Contract No. DE-AC36-08GO28308
15013 Denver West Parkway

Golden, CO 80401

303-275-3000 • www.nrel.gov 


\section{NOTICE}

This report was prepared as an account of work sponsored by an agency of the United States government. Neither the United States government nor any agency thereof, nor any of their employees, makes any warranty, express or implied, or assumes any legal liability or responsibility for the accuracy, completeness, or usefulness of any information, apparatus, product, or process disclosed, or represents that its use would not infringe privately owned rights. Reference herein to any specific commercial product, process, or service by trade name, trademark, manufacturer, or otherwise does not necessarily constitute or imply its endorsement, recommendation, or favoring by the United States government or any agency thereof. The views and opinions of authors expressed herein do not necessarily state or reflect those of the United States government or any agency thereof.

This report is available at no cost from the National Renewable Energy Laboratory (NREL) at www.nrel.gov/publications.

Available electronically at SciTech Connect http:/www.osti.gov/scitech

Available for a processing fee to U.S. Department of Energy and its contractors, in paper, from:

U.S. Department of Energy

Office of Scientific and Technical Information

P.O. Box 62

Oak Ridge, TN 37831-0062

OSTI http://www.osti.gov

Phone: 865.576.8401

Fax: 865.576.5728

Email: reports@osti.gov

Available for sale to the public, in paper, from:

U.S. Department of Commerce

National Technical Information Service

5301 Shawnee Road

Alexandria, VA 22312

NTIS http://www.ntis.gov

Phone: 800.553 .6847 or 703.605 .6000

Fax: 703.605.6900

Email: orders@ntis.gov 


\section{Acknowledgments}

This work was supported by the Solar Energy Technologies Office at the U.S. Department of Energy. The authors would like to thank the following individuals and organizations for their thoughtful review of this work: David Bielen (NREL), Jack Hoskins (DOE), Ben Leibowicz (University of Texas-Austin), and Odette Mucha (DOE). The authors would like to thank the following individuals and their companies for participating in a survey of PV installers: Jose Alvarez (Sunworks, Inc.), Seth Atchue (Sunworks, Inc.), Tara Bono (SunPower by EmPower Solar), Ben Burnett (Earthlight Solar Solutions), Brandon Hart (Direct Energy Solar), Chad Lawrence (RGS Energy), Daniel Mello Guimaraes (Boston Solar), and Tom Wu (Invaleon Solar). The authors would like to also thank Vikram Aggarwal, Nick Liberati, Sara Matasci, and Luke Tarbi of EnergySage for their collaboration on this project, Chang Liu (NREL) for data support, and Mike Meshek (NREL) for editorial support. 


\section{Executive Summary}

Distributed solar photovoltaic (PV) markets are relatively non-transparent; PV price and product information is not readily available, searching for this information is costly (in terms of time and effort), and customers are mostly unfamiliar with the new technology. Customers often decide to adopt PV based on only a few quotes and limited PV product information. In part because of low PV market transparency, customers do not always find the best deals, and some customers may forego adoption because they are unable to find acceptable prices. Economic theory suggests that more market transparency - in other words, improved access to price and product information - should increase competition, reduce prices, and improve product quality. Quote aggregation, where third-party companies collect PV quotes on behalf of customers, may be one way to increase PV market transparency.

In this paper, we analyze data from a U.S. quote aggregator to study the effects of transparency on PV markets. To provide additional context for our results, we also summarize key points from a set of interviews with PV installers regarding their experience using quote aggregation. From the data, we find that quote aggregation drives installers to offer lower prices. Using a paired difference approach, we find that PV installers bid \$0.24 per watt (W) lower on the aggregator's quote platform than when they bid directly to the same customers, on average. Further, we find that prices decline as customers receive more quotes because of increased installer competition. Figure ES-1 shows how quote price distributions become increasingly skewed toward lower prices as the number of expected competitors increases.

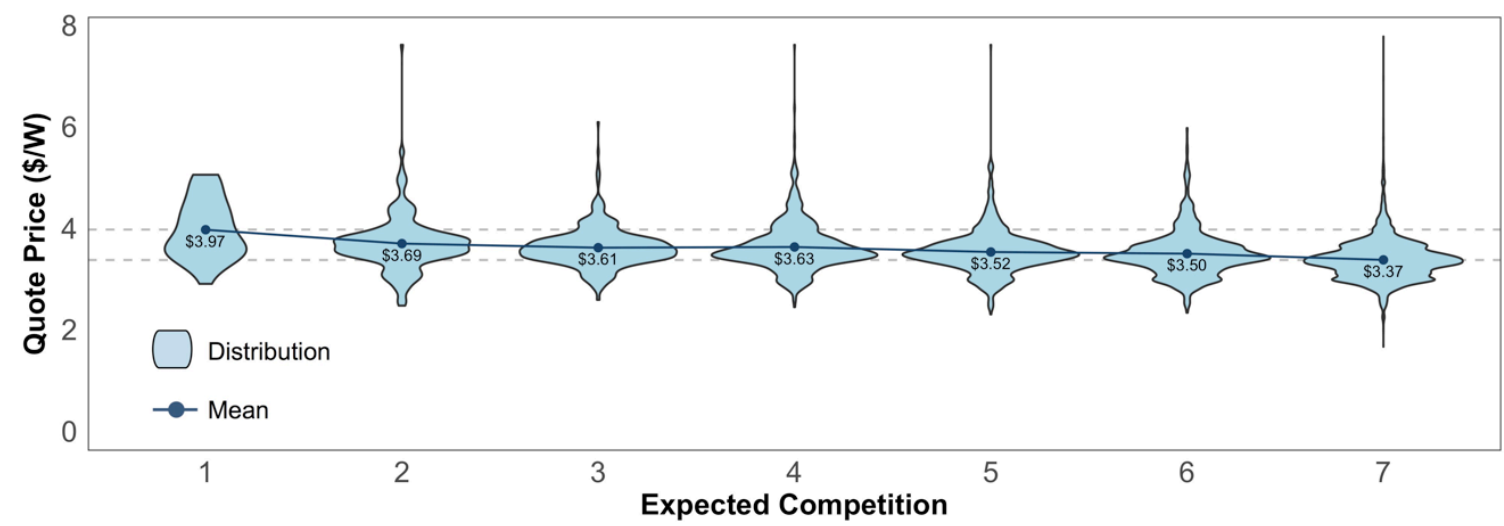

Figure ES1. Price distributions by number of expected competitors, based on quotes made in California in Q4 2016

Our results illustrate the value of transparency in PV markets; customers obtain lower prices when more quotes are available and more installers compete for customers. Some installers interviewed for this study stated that overemphasis on low prices may drive installers to compete by offering lower-quality equipment on quote platforms. However, we find that only about one in three quote aggregation customers select the lowest-priced quote and that customers are more likely to select quotes with premium (high-efficiency) panels. The data indicate that at least some customers evaluate offers based on multiple dimensions, including product quality and that highquality products can compete on quote aggregation platforms. Overall, we conclude that quote aggregation increases PV market transparency, increases installer competition, and results in lower prices. 


\section{Table of Contents}

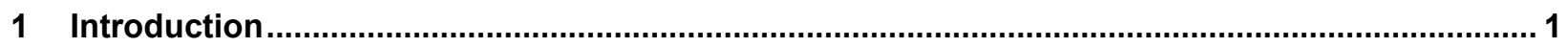

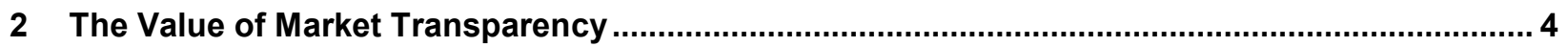

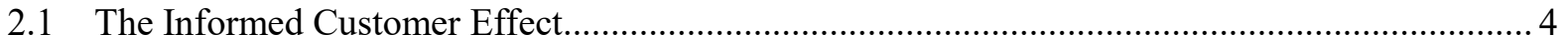

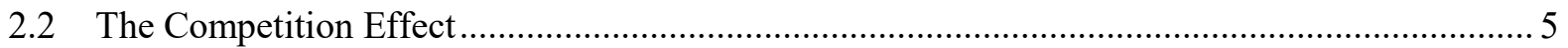

2.3 The Value of Market Transparency: Research to Date .............................................................. 6

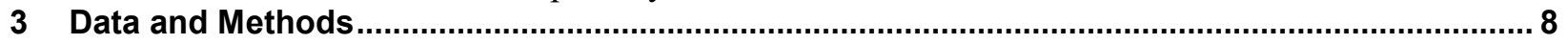

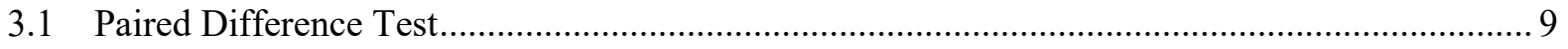

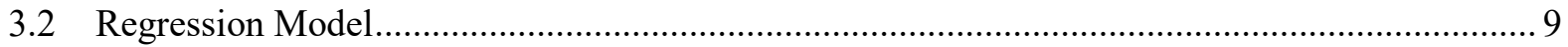

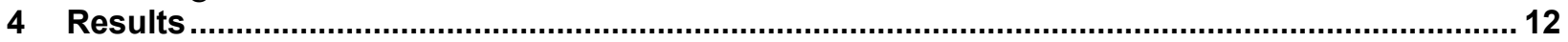

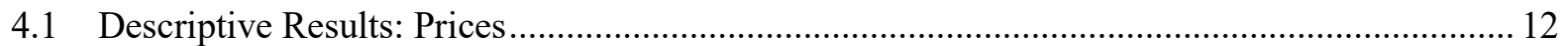

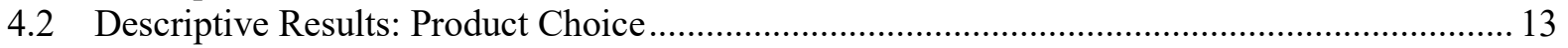

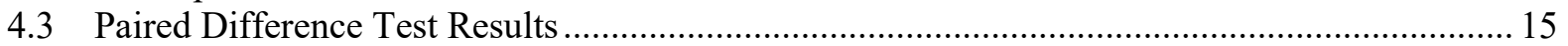

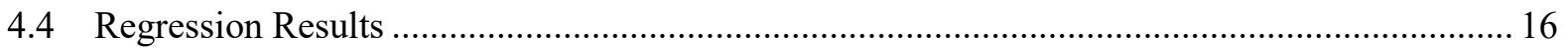

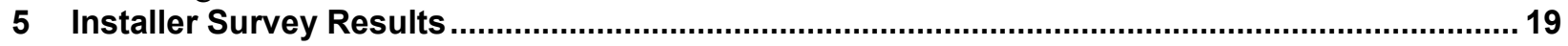

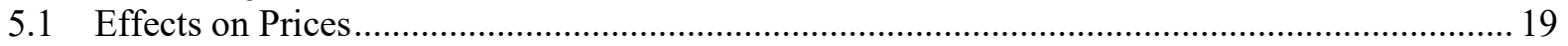

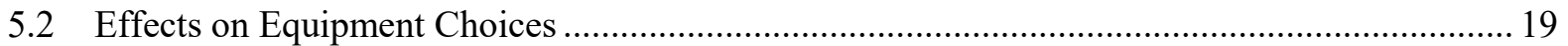

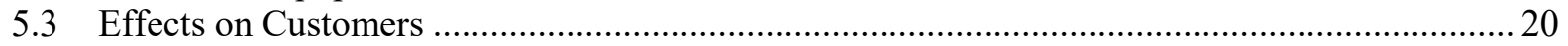

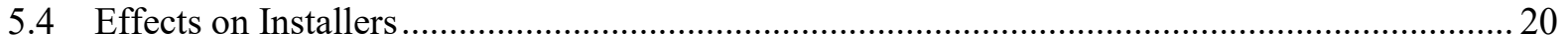

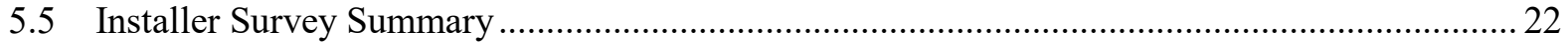

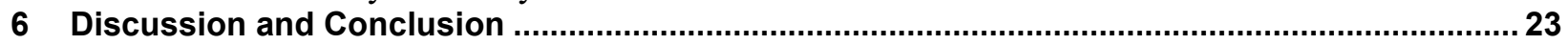

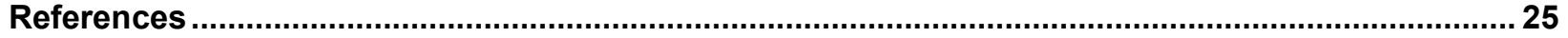




\section{List of Figures}

Figure ES1. Price distributions by number of expected competitors, based on quotes made in

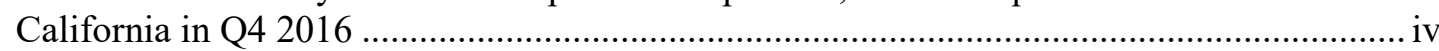

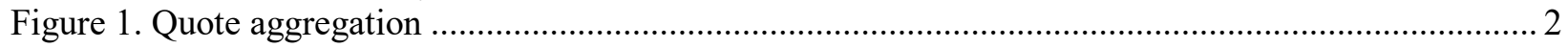

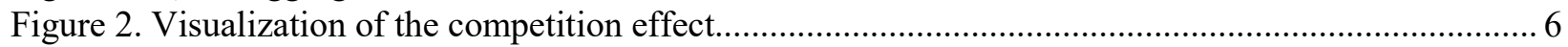

Figure 3. Relationship between number of interested bidders and quotes received ............................... 10

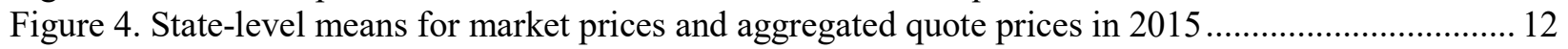

Figure 5. Installer-level mean market prices and aggregated quote prices in 2015 ............................... 13

Figure 6. Percentage of quotes/systems by data set that offered economy, standard, and premium

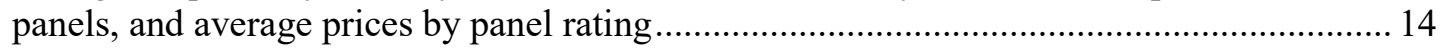

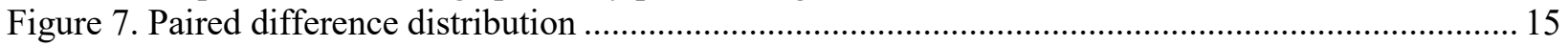

Figure 8. Paired difference distribution of residuals ......................................................................... 16

Figure 9. Bid price distributions by expected number of competitors in California, Q4 2016 ................ 18

Figure 10. State-level differences between mean price for quotes with seven expected competitors and

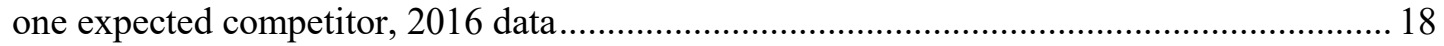

\section{List of Tables}

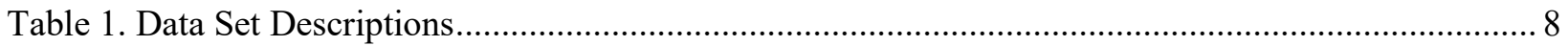

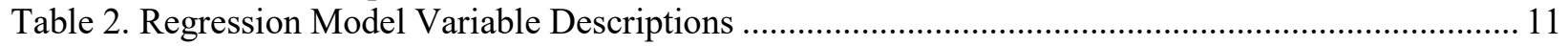

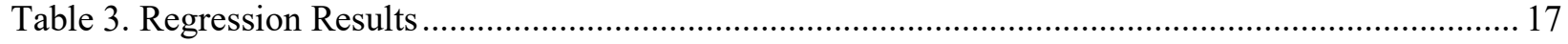

Table 4. Interview Summary: Effects of Quote Aggregation ................................................................ 22 


\section{Introduction}

Market transparency refers to the degree of customer awareness of product options and fair market prices for a given good. ${ }^{1}$ Distributed solar photovoltaic (PV) markets are relatively nontransparent. PV prices are not readily available because installers have little incentive to advertise prices, which is consistent with other service industries. Further, PV is a new, unfamiliar, and infrequently purchased good. Low market transparency prevents some PV customers from finding the best possible deals (Gillingham et al. 2016; Nemet et al. 2017), and it may stymie PV deployment if some customers forego adoption because they are unable to find an acceptable price. In this paper, we study the value of transparency in distributed PV markets. We use quote data to analyze how access to PV price and product information affects PV prices and customer outcomes. We supplement our empirical analysis with key findings from a set of interviews with PV installers.

Low PV market transparency is a result of the "hold-up problem," which is commonly observed in other markets that involve contractual performance. The hold-up problem occurs when one party divulges information that gives another party more bargaining power in contractual negotiations, allowing one party to "hold up" the other. PV installers lose bargaining power by advertising prices. Installation costs vary from home to home because of site characteristics such as roof slope and material. Installers that advertise prices are subject to the hold-up problem when customers at higher-cost sites use the installer's advertised prices to negotiate a lowerpriced (and possibly unprofitable) installation. Thus, PV installers have little incentive to reveal prices (Hart and Moore 1988; Rogerson 1992; Noldeke and Schmidt 1995; Anderson and Renault 2006; Hoppe and Schmitz 2011).

PV is also a new technology and an infrequently purchased good, which are factors that contribute to low market transparency. Most prospective PV customers are largely unfamiliar with PV and ill-equipped to evaluate different product options. Further, relatively low PV penetration (about 1\% of U.S. households) means most customers can seek advice from few, if any, peers that have adopted PV. Finally, PV is an infrequently purchased good. A typical PV system lasts more than 20 years, meaning that repeat PV customers have to apprise themselves of the current state of the market with each repeat purchase. The infrequency of PV purchasing further reduces PV market transparency.

Because PV price information is unavailable, customers "search" for PV prices by soliciting quotes from individual installers. PV customers must compile information, find potential installers, host site visits, and incur other search costs to obtain quotes. Owing to search costs, some customers must satisfice by accepting the lowest obtained price rather than the lowest possible price (Stigler 1961). Most customers make adoption decisions based on only two or three quotes (EnergySage 2017; Moezzi et al. 2017). Other customers may forego adoption altogether if an acceptable price is not obtained through search. Limited customer search reduces installer competition, given that installers compete against only the sample of rivals that submit bids rather than the full population of potential rivals. This reduced competition may induce

\footnotetext{
${ }^{1}$ Market transparency may also be defined to include the degree of supply-side transparency; however, this study focuses on customer-side transparency.
} 
installers to "bid up" prices, increasing the probability that some customers forego adoption because of an unsuccessful search.

The causes and outcomes of low PV market transparency have analogues in other service industries. Roofing, heating and air conditioning, and hot water heater installations/replacements similarly represent infrequent purchases, where contractors are unlikely to divulge detailed price information because of the hold-up problem. As with PV, homeowners must search for quotes from individual contractors for these services, and they may satisfice with high but acceptable prices after conducting limited searches. Nonetheless, markets for these services are arguably more transparent than PV markets. Most homeowners have peers (e.g., neighbors) that can provide insights on current market prices for these services based on recent experience. Further, various industry and consumer groups have created price guides and online cost estimators for these services. Homeowners therefore may be generally aware of acceptable price points for these services before beginning their search.

Markets for services like PV installation may never become fully transparent because of the hold-up problem. However, customer experience, peer effects, and resources such as price guides can increase transparency in these markets. Quote aggregation has emerged as one means of increasing PV market transparency. Quote aggregators are companies that collect quotes on behalf of customers (Figure 1). Aggregators collect relevant customer information (e.g., address and electricity use) and pass this information to an installer network. Installers make quotes based on the customer's information and bid to the customer via an online quote platform. Quote aggregation protects installers from the hold-up problem by allowing installers to develop site-specific quotes. At the same time, customers have access to more quotes and are more likely to obtain acceptably low prices. Further, installers may be induced to offer lower prices on the quote platform because of increased competition. Quote aggregation is a small but growing piece of the U.S. residential PV market. In 2016, about 3\% of customers procured PV through a quote aggregator's bidding platform, which is up from about 1\% of customers in 2013 (Mond 2017). Quote aggregation should continue to become more common as customers become more comfortable with PV procurement through online platforms.
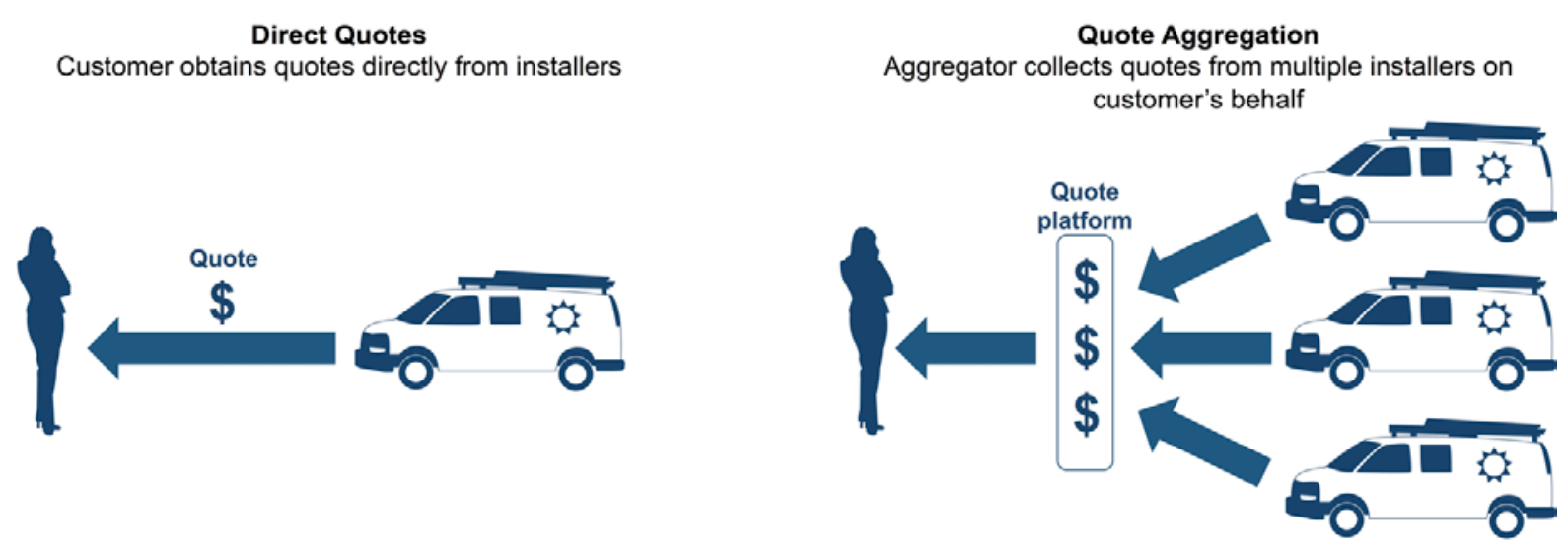

Figure 1. Quote aggregation 
This paper uses data from the U.S. quote aggregator EnergySage and interviews with EnergySage installers to study the value of market transparency for distributed PV. ${ }^{2}$ Our study uses residential data; however, our findings should broadly apply to commercial PV. In Section 2, we use economic theory to make several hypotheses on the value of transparency for PV markets. In Section 3, we summarize the data and methods used to test our hypotheses. We present the results of our study in Section 4. In Section 5, we present findings from a survey of EnergySage installers on the effects of quote aggregation on installer pricing behavior. We conclude with a discussion of the implications of our findings in Section 6.

\footnotetext{
${ }^{2}$ EnergySage maintains a nationwide network of more than $400 \mathrm{PV}$ installers, all of which are prescreened based on years of experience, certifications, warranties, quality of installations, and reputation.
} 


\section{The Value of Market Transparency}

Economic theory suggests higher market transparency generally results in lower prices and better customer value. ${ }^{3}$ In this section, we summarize this theory to develop two hypotheses about the value of transparency for distributed PV markets. The hypotheses are not mutually exclusive. We discuss economic theories in non-technical language; more complex models are available through the references.

\subsection{The Informed Customer Effect}

Consider a simple PV market with two types of customers: informed customers who are familiar with PV and demand high-quality products at competitive prices, and uninformed customers who are unfamiliar with PV and simply select the lowest available price. Economic theory shows that customers in markets with many informed customers will obtain better prices and better values than customers in markets with few informed customers (Stigler 1961; Akerlof 1970; Salop and Stiglitz 1977; Varian 1980; Tirole 1988). To understand why, first assume all PV customers are uninformed and customers simply select the lowest-priced bids. Installers would charge the highest possible prices on the lowest-cost, lowest-quality equipment. Installers of high-quality equipment would be uncompetitive, as uninformed customers would never accept their higher prices. This scenario is known as the "lemons" or "race to the bottom" problem, whereby the market would be flooded with low-quality budget systems.

Now assume the PV market consists of a mix of informed and uninformed customers. In this scenario, installers lose customers when offering low-quality equipment at higher prices to informed customers. Installers have an incentive to offer higher-quality equipment at competitive prices when at least some customers are informed. Further, if installers cannot distinguish informed and uninformed customers, installers will offer higher quality equipment even when bidding to uninformed customers. Hence, economic theory shows that all customers, including uninformed customers obtain higher quality products at better values when more customers are informed.

Because customers have more access to price and product quality information, more transparent markets will have more-informed customers than non-transparent markets. This provides the basis for our first hypothesis:

\section{Hypothesis 1: The Informed Customer Effect}

PV market transparency results in a more-informed customer base, which drives installers to offer lower prices and superior products.

\footnotetext{
${ }^{3}$ This is a general result; see, for example, Salop and Stiglitz (1977), Varian (1980), Tirole (1988), Schultz (2009), and $\mathrm{Gu}$ and Wenzel (2011). However, exceptions exist in certain economic conditions; see Boone and Pottersz (2006), Soh, Markus, and Goh (2006), and Zhang and Jiang (2014).
} 


\subsection{The Competition Effect}

$\mathrm{PV}$ installers earn profits by adding margins above installation costs to their bid prices. However, installers face a dilemma; higher margins mean higher prices and profits, but customers are less likely to accept higher prices. Competition exacerbates this dilemma. Installers are less likely to win high-priced offers when more rivals submit bids. As a result, installers should strategically offer lower prices in more transparent markets where customers obtain more quotes from more installers (Riley and Samuelson 1981; Carr 1983; McAfee and McMillan 1987; Levin and Smith 1994; Rothkopf and Harstad 1994; Lorentziadis 2016).

To understand this effect, we develop a simple model of how competition affects prices in bidding processes based on the strategic bidding literature. Let $p$ represent an installer's bid price and $c$ the installer's cost to install a system. The installer's margin is $p-c$. Let $W(p, n)$ represent the probability that an installer wins their bid if they offer price $p$ and $n$ installers make bids, where $W(p, n)$ is decreasing in both $p$ and $n$. In other words, the probability that an installer wins its bid decreases as prices increase or as more rivals submit bids, all else being equal. ${ }^{4}$ The installer's expected profit $(\pi)$ can be written as $\pi=W(p, n) \times(p-c)$. That is, the expected profit is the product of the installer's margin and the probability of winning the bid at that margin given the number of rival bidders.

Figure 2 illustrates the bidder's dilemma with the functional form of $W(p, n)=(1-\log (p))^{n-1}$ as an example. ${ }^{5}$ The left pane of Figure 2 assumes $n=1$, and it depicts how the installer's profit initially increases with higher prices because of higher margins but then falls because of low bidwinning probabilities at high prices. The optimal bid price is depicted by the apex of the parabola in the left pane of Figure 2, which is the point at which expected profits are maximized. The right pane of Figure 2 depicts the optimal bid price and bid-winning probability as functions of the number of bidders. The figure shows how the bid-winning probability declines as more bidders participate. The optimal bid price likewise falls as more bidders participate. In other words, all installers have lower optimal bids when facing more competition. Translated to market transparency, this economic theory implies installers have lower optimal bids when customers obtain more quotes.

\footnotetext{
${ }^{4}$ More formally, $\partial \mathrm{W} / \partial \mathrm{p}<0, \partial \mathrm{W} / \partial \mathrm{n}<0$.

${ }^{5}$ The exponential form is consistent with functional forms commonly applied in auction theory literature. For surveys of auction theory, see McAfee and McMillan (1987), Rothkopf and Harstad (1994), and Lorentziadis (2016).
} 

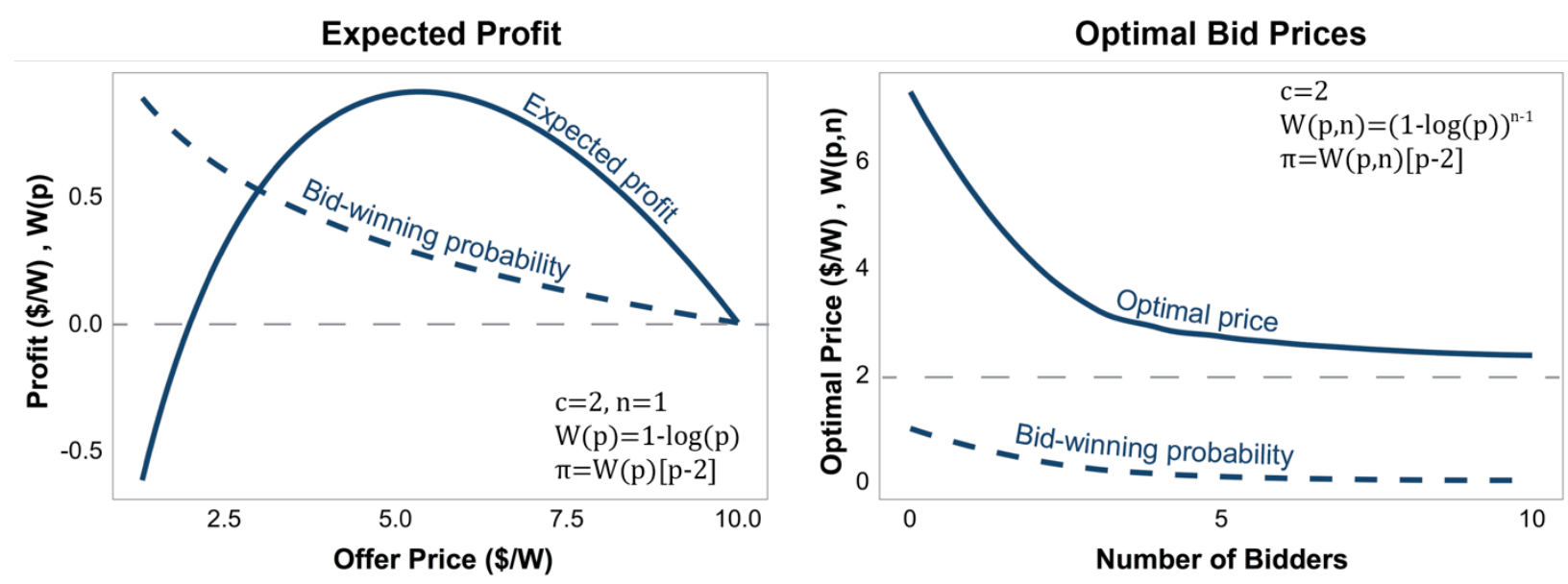

Figure 2. Visualization of the competition effect

The figure represents an installer with cost $c=\$ 2 / \mathrm{W}$ (watt). The bid-winning probability is represented by a function $W(p)=(1-\log (p))^{n-1}$. This functional form was chosen for illustrative purposes.

The dynamics illustrated in Figure 2 provide the basis for our second hypothesis:

\section{Hypothesis 2: The Competition Effect}

PV market transparency results in more intense competition when customers obtain more quotes, which drives installers to offer lower prices.

The competition effect would not be unique to the PV industry. For instance, survey data in the construction industry suggest that construction contractors assess their competition when determining bids (Ahmad and Minkarah 1988; Mochtar and Arditi 2001). These studies show that, consistent with the bidding model depicted in Figure 2, construction contractors tend to set prices according to their costs plus some margin determined in part by market conditions such as competitive intensity.

\subsection{The Value of Market Transparency: Research to Date}

Baye, Morgan, and Scholten (2003), who study the value of transparency in online price platforms similar to EnergySage, compare prices for consumer electronics on an online price comparison website versus prices obtained directly from stores. They find the average minimum posted price on the online platform was $16 \%$ lower than the average market price. The authors argue this price difference reflects the "value of information" provided by the online platform. Further, they find the value of information increases as more prices are posted on the online platform. That is, customers tend to obtain lower prices when more retailers provide prices via the platform.

Similarly, Brynjolfsson and Smith (2000) study differences in online and in-store shopping behavior and outcomes. They find customers obtain lower prices through online shopping than in-store shopping, on average. They note that online shoppers obtain lower prices, in part, because online shopping is quicker and easier. In other words, online markets are more transparent in that customers tend to evaluate more products and prices than through instore shopping. 
Several studies provide evidence of the value of transparency for PV markets specifically. Seel, Barbose, and Wiser (2014) cite market transparency as one of the reasons that installed PV prices are lower in Germany than they are in the United States. They argue the prevalence of quote aggregators in Germany results in lower prices than in the United States, where quote aggregation is less common. Gillingham et al. (2016) find that installed PV prices are generally lower in markets with more active installers and in markets with more educated customers. These results suggest that customers who are more informed - either from access to more quotes or from education level — obtain lower prices than customers who are less informed. Nemet et al. (2017) find that installed PV prices show less variation when customers have more neighbors that have installed PV, suggesting that peer effects result in more-informed customers. Further, Nemet et al. (2017) find that PV prices show less variation in areas where third-party quote services are available, ${ }^{6}$ suggesting that easier access to $\mathrm{PV}$ prices reduces price dispersion.

The use of installed price data rather than quote data is a limitation across most PV price studies to date. Installed price data exclude information from quotes that were not selected by customers, even though knowing how installers bid, even when bids are unsuccessful, is important for competition studies. In this study, we use quote data rather than installed system price data to study the effects of market transparency on installer bidding behavior. Quote data allows us to control for otherwise unobserved site-level differences. For instance, installed price differences between homes may reflect differences about the homes (e.g., roof pitch) rather than installer or system differences. With quote data, comparisons of quotes made to the same customers automatically control for these site-level differences. In addition, previous studies have studied competition effects through proxies such as the density of installers in a given area. In this paper, we leverage our unique data set to develop an alternative estimate of competitive intensity based on the number of expected competitors per customer.

\footnotetext{
${ }^{6}$ The study uses data from a third-party quote provider that generally connects customers to a single installer within its network. This business model differs slightly from the quote aggregation model, where the aggregator connects customers to multiple installers.
} 


\section{Data and Methods}

EnergySage provided data on 72,720 residential PV quotes made to 24,052 customers between 2013 and early 2017 to support our analysis. We use the term aggregated quotes to refer to quotes from this data set.

EnergySage prompts customers to voluntarily upload quotes received by installers outside of the EnergySage installer network. ${ }^{7}$ We use the term direct quotes to refer to quotes received directly from installers. The direct quote data set consists of 294 quotes that can be matched with 260 customers in the aggregated quote data set.

Installed price data were obtained from the Lawrence Berkeley National Laboratory's Tracking the Sun data set (Barbose and Darghouth 2016). We use market price data as a benchmark for comparing aggregated quotes against the overall PV market. Our Tracking the Sun data set consists of 128,228 systems installed from 2013 through the end of 2015 . $^{8}$ We use the term market prices to refer to Tracking the Sun data. Table 1 summarizes the three data sets.

Table 1. Data Set Descriptions

\begin{tabular}{llll}
\hline & Aggregated Quotes & Direct Quotes & Market Prices \\
\hline Description & $\begin{array}{l}\text { Quotes delivered to } \\
\text { customers via EnergySage }\end{array}$ & $\begin{array}{l}\text { Quotes delivered to } \\
\text { customers from installers }\end{array}$ & Installed prices \\
N & 72,720 & 294 & 128,228 \\
Time coverage & $2013-2016$ & $2014-2016$ & $2013-2015$ \\
Geographic coverage & 35 states and DC & 27 states and DC & 24 states and DC \\
\hline
\end{tabular}

For the sake of analytical simplicity, all three data sets exclude quotes without a customer ownership option and installed prices representing appraised values for third-party owned systems. ${ }^{9}$ All prices represent offers or installed prices for customer-owned systems. Although third-party owned systems still comprise around $40 \%$ of the residential PV market, customers and installers have recently begun to shift toward increasing customer ownership (Litvak 2017).

We develop two approaches to measure the effects of market transparency: a paired difference test and a regression approach.

\footnotetext{
${ }^{7}$ The voluntary upload introduces a potential self-selection bias, but we have no reason to believe that customers who received an external quote and chose to upload the quote vary systematically from customers who received an external quote but did not upload it.

${ }^{8}$ For both aggregated quotes and market prices, we dropped observations with prices that were below $\$ 1 / \mathrm{W}$ or above $\$ 25 / \mathrm{W}$ as probable data entry errors, which is consistent with Gillingham et al. (2016). For market prices, we also dropped observations that reported appraised values for third-party owned systems.

${ }^{9}$ Third-party owned systems refer to purchases in which the customer procures PV through a lease or power purchase agreement while a third party retains ownership of the system.
} 


\subsection{Paired Difference Test}

A paired difference test measures differences in the values of two variables for the same observation. In our case, we measure differences in internal and external quote prices made to the same customer:

$$
\text { diff = aggregrated quote price }- \text { direct quote price }
$$

Consistently negative values of $\operatorname{diff}$ provide evidence that aggregated quotes are generally lower than direct quotes. A paired difference $t$ test can be used to evaluate the statistical significance of paired differences; see O'Shaughnessy and Margolis (2017) for a detailed description of the paired difference methodology. Evidence that aggregated quotes are consistently lower than direct quotes would support hypotheses that market transparency results in lower prices because of either informed customers (Hypothesis 1) or increased competition (Hypothesis 2).

\subsection{Regression Model}

The Competition Effect Hypothesis (Hypothesis 2 in Section 2) states that installers offer lower prices when customers receive more quotes. The hypothesis implies that installers have some way of estimating how many quotes a customer will receive and that installers react to this expected competition. In other words, the competition hypothesis is that customers obtain lower prices when installers expect to compete against more installers. We develop a regression model to test this hypothesis.

Installers in the EnergySage network do not know which rival installers submit bids to which customers, nor do installers know the specifics of rival bids. However, EnergySage allows installers to see how many installers have expressed "interest" in bidding to each property. ${ }^{10}$ As of mid-2016, EnergySage limits each property to receiving quotes from no more than seven interested installers. The number of "interested" installers is highly correlated with the number of quotes that customers ultimately receive (Figure 3 ). Therefore the number of interested bidders provides an estimate of the number of expected competitors for any given customer. We refer to the number of interested installers as expected competition. Note that the expected competition is at least one for customers that received quotes.

\footnotetext{
${ }^{10}$ About $20 \%$ of customers received more than seven quotes before this change was instated. The results in Section 4 are not sensitive to this policy change; the results are robust (statistically significant) when the data are bifurcated into observations before and after the policy change.
} 


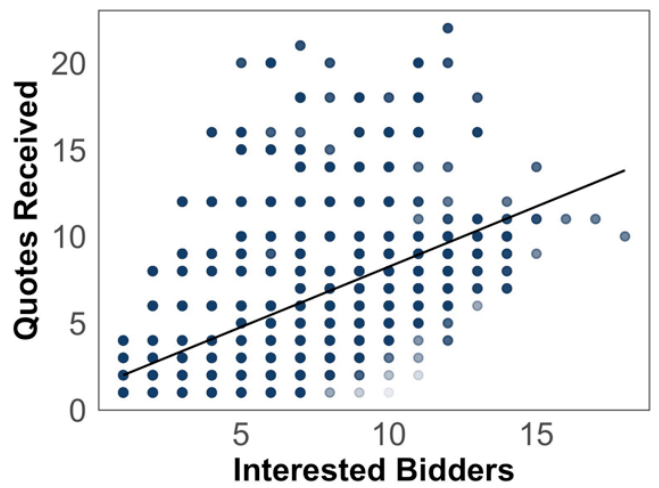

Figure 3. Relationship between number of interested bidders and quotes received

The competition effect may not be linear. Most strategic bidding models assume the number of competitors has a non-linear effect on prices (see Riley and Samuelson 1981; McAfee and McMillan 1987; Rothkopf and Harstad 1994; Lorentziadis 2016). In other words, moving from one to two expected competitors has a greater effect on prices than moving from two to three expected competitors, and so on. We can account for this non-linearity by log-transforming the variable for expected competition.

We model the effects of expected competition on prices through the following model (in matrix form for notational simplicity):

$$
p=\operatorname{comp} \lambda+X \beta+Q T R+C T Y+I N S T+\varepsilon
$$

Where $p$ is the offer price ( $\$ / \mathrm{W}), \operatorname{com} p$ is the natural logarithm of expected competition (the number of interested installers), $\lambda$ is the competition effect, $X$ is a matrix of control variables, $Q T R$ is a quarterly fixed effect, $C T Y$ is a county fixed effect, INST is an installer fixed effect, and $\varepsilon$ is an error term. ${ }^{11}$ The matrix $X$ consists of controls for system size in kilowatts $(\mathrm{kW})$, system size squared, the customer's annual home electricity use, module rating (premium, standard, or economy - see Section 4.2), and dummies for whether the quoted system uses micro-inverters or optimizers. Table 2 describes the model's variables in more detail.

\footnotetext{
${ }^{11}$ Fixed effects allow models to control for variation across time, location, or entities. For instance, quarterly fixed effects control for the fact that prices may vary across quarters independently of other variables in the model.
} 
Table 2. Regression Model Variable Descriptions

\begin{tabular}{lll}
\hline Variable & Units & Explanation \\
\hline p: price & $\$$ W & - \\
\hline comp: expected competition & $\begin{array}{l}\text { Number of interested installers } \\
\text { (logged) }\end{array}$ & Logged to account for non-linearity \\
\hline QTR: quarter & Fixed effect & Control for time effects \\
\hline CTY: county & Fixed effect & $\begin{array}{l}\text { Control for geographic differences } \\
\text { in prices }\end{array}$ \\
\hline INST: installer & Fixed effect & $\begin{array}{l}\text { Control for installer price } \\
\text { differences }\end{array}$ \\
\hline System size & $\mathrm{kW}$ & $\begin{array}{l}\text { Control for economies of scale in } \\
\text { system size }\end{array}$ \\
\hline System size squared & $\mathrm{kW}{ }^{2}$ & $\begin{array}{l}\text { Control for diminishing returns to } \\
\text { economies of scale }\end{array}$ \\
\hline Annual home electricity use & $\mathrm{kWh/year}$ & $\begin{array}{l}\text { Control for value-based pricing } \\
\text { (installers may bid higher prices for } \\
\text { customers with larger bills) }\end{array}$ \\
\hline Module rating & Factor: economy (ref), ${ }^{\text {a }}$ standard, \\
premium & $\begin{array}{l}\text { Control for price differences } \\
\text { because of panel cost }\end{array}$ \\
\hline Inverter type & $\begin{array}{l}\text { Factor: micro-inverter (ref) }{ }^{*}, \text { DC } \\
\text { optimizer, string }\end{array}$ & $\begin{array}{l}\text { Control for price differences } \\
\text { because of inverter cost }\end{array}$ \\
\hline
\end{tabular}

a Regression models require one factor value to be used as the reference. Coefficients may be interpreted as an effect on price relative to the reference value.

The coefficient $\lambda$ measures the change in price that results from a change in expected competition. Because we take the log of competition, $\lambda$ can be interpreted as the increase in price $(\$ / W)$ resulting from a $100 \%$ increase in the number of potential competitors (e.g., moving from one to two rivals). Significantly negative values of $\lambda$ would provide support for Hypothesis 2 that market transparency results in lower prices because of increased competitive intensity. 


\section{Results}

Results are presented in four sections. Descriptive results are provided in Section 4.1 (prices) and Section 4.2 (product choice) to contextualize the evaluative results. Descriptive results are limited to data from 2014 and 2015, given that all three data sets overlap in these two years. Section 4.3 provides the results of the paired difference tests. Section 4.4 presents regression results.

\subsection{Descriptive Results: Prices}

In 2015, aggregated quote prices were about $\$ 0.32 / \mathrm{W}(8 \%)$ lower than direct quote prices and about $\$ 0.80 / \mathrm{W}(18 \%)$ lower than market prices, on average. These descriptive results suggest installers offer lower prices on the quote aggregation platform. We explore several potentially confounding factors that could explain the significant difference between aggregated quote prices and market prices.

Time is one potentially confounding factor. The market prices reflect prices of installed systems and generally reflect prices that were developed earlier in the year. With falling PV prices over time, it is possible some of the price difference is due to the time lag in installed prices. However, time lag effects only explain a small portion of the observed price difference. Aggregated quote prices for systems quoted in 2014 were about $\$ 0.74 / \mathrm{W}$ lower than market prices for systems installed in 2015. In other words, aggregated quote prices remain significantly lower even after conceding a lag of an entire year, which is much longer than typical installation times.

Geography may be an additional confounding factor; however, the observed price difference appears to be robust across states (Figure 4), with only one exception in New Hampshire. Differences between market prices and aggregated quote prices are lower in the Northeast and higher in the South and the West. Geographic differences suggest increased market transparency may have different effects in different areas.

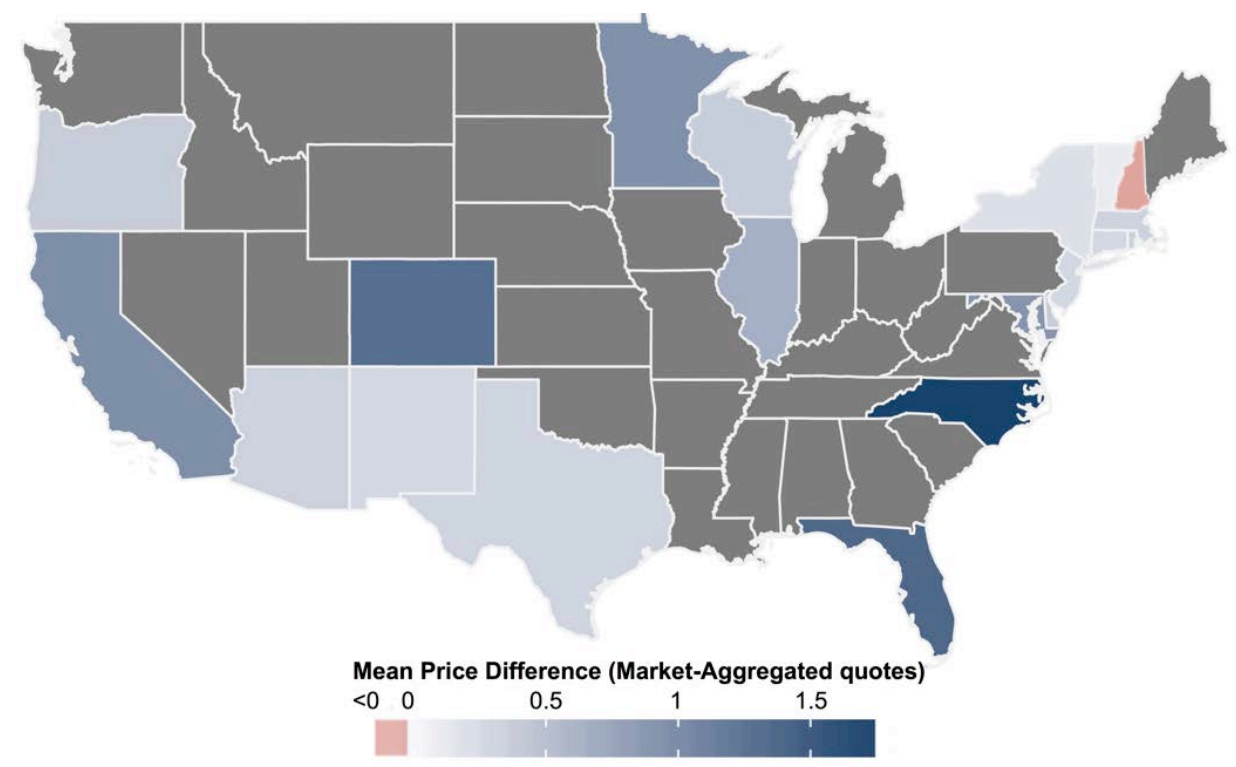

Figure 4. State-level means for market prices and aggregated quote prices in 2015 
The composition of installers is an additional potentially confounding factor. Price differences may indicate differences in installers, given that EnergySage works with an installer network that may not be representative of the PV installation industry as a whole. In 2015, there were 99 installers that submitted quotes through EnergySage that also had at least one installed price included in the market price data set. The average aggregated quote price of $64(65 \%)$ of these installers was lower than the installer's average market price (Figure 5). In other words, about two-thirds of installers offered lower prices when bidding on the quote platform. On average, an installer's mean aggregated quote price was $\$ 0.29 / \mathrm{W}$ lower than their average market price.

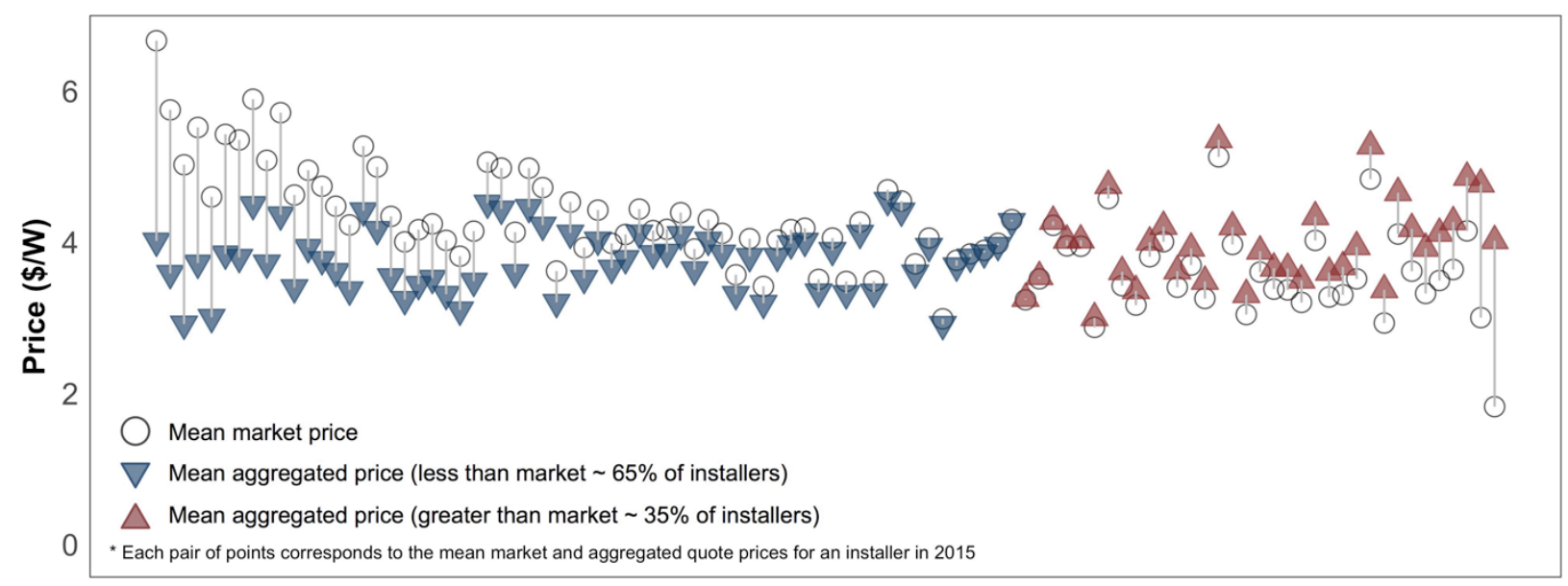

Figure 5. Installer-level mean market prices and aggregated quote prices in 2015

Last, it is possible that quote prices vary systematically from finalized installation prices. Customers may request changes in equipment or other factors that could cause the final install price to deviate from the initial offer quote price. In 2015, accepted aggregated quotes were about $\$ 0.10 / \mathrm{W}(2.6 \%)$ higher than other quotes on the quote aggregation platform, on average. The average accepted quote price is $\$ 0.70 / \mathrm{W}(16 \%)$ lower than the average market price in 2015 . This difference is slightly smaller than the $\$ 0.80 / \mathrm{W}$ difference between all aggregated quotes and market prices. Thus, differences between finalized and pending quote prices may explain some of the observed price difference.

\subsection{Descriptive Results: Product Choice}

Different customers have different preferences for PV module and inverter brands and models. Customers with limited roof space may prefer higher-cost high-efficiency panels that generate more power per unit of roof space. Customers with adequate roof space may prefer lower-cost economy modules with standard efficiency ratings. Further, some customers may be willing to pay premiums for longer-term warranties. We use the following rating system to categorize PV panels according to efficiency and warranty: ${ }^{12}$

- Premium panels: Panel brands with average efficiency greater than $20 \%$ and a materials warranty of at least 20 years.

- Standard panels: Panel brands with average efficiency greater than $16.5 \%$ and a materials warranty of at least 15 years (excluding premium panels).

\footnotetext{
12 This panel rating system was developed by EnergySage with support from NREL.
} 
- Economy panels: All other panel brands.

Figure 6 illustrates the breakdown of panel ratings for the three data sets, limited to 2015 data. Standard panels comprise the majority of offerings in all three data sets. Proportionally fewer aggregated quotes offered premium panels than direct quotes and systems in the market price data. ${ }^{13}$ Figure 6 also shows average prices by data set and panel type. The differences in prices across the data set are particularly stark for premium panels; aggregated quote prices for systems with premium panels were about $\$ 0.52 / \mathrm{W}$ less expensive on the quote platform than in the market price data and about $\$ 0.94 / \mathrm{W}$ less than in the direct quotes.

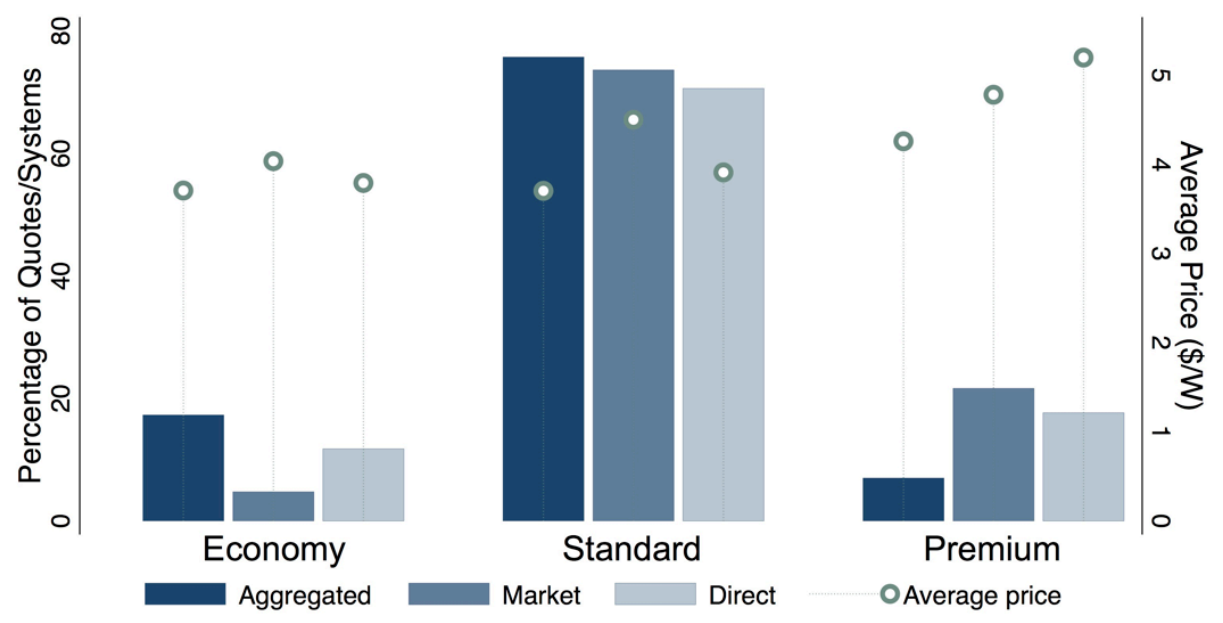

Figure 6. Percentage of quotes/systems by data set that offered economy, standard, and premium panels, and average prices by panel rating

Figure note: Bars display the percentage of quotes/systems using each type of panel (left axis), points display the average price of aggregated quotes, direct quotes, and market prices by panel type (right axis)

The results in Figure 6 suggest installers offer different types of products in different market environments. One possible explanation offered by installers (see Section 5) is that quote aggregation increases customer sensitivity to prices while reducing customer attention to product choice. Installers face little incentive to offer premium equipment to price-centric customers and may, at least initially, offer economy or standard panels rather than premium panels. However, the data indicate that most quote platform customers are not price-centric; only about $38 \%$ of customers that have adopted PV on the quote platform selected the lowest available bid price. ${ }^{14}$ Further, quotes with premium panels are about $50 \%$ more likely to be accepted than quotes with other panels, suggesting that customers show a preference for premium panels on the quote platform. See Section 5 for further discussion of the effects of quote aggregation on product choice based on interviews with installers.

\footnotetext{
${ }^{13}$ It should be noted that panel information was only available for about half of direct quotes, and that these data may be biased if installers tend to omit panel information when offering economy panels.

${ }^{14}$ Limited to customers that received at least two quotes
} 


\subsection{Paired Difference Test Results}

The aggregated and direct quote data sets yield 1,108 unique pairings of aggregated and direct quotes made to 265 customers. Aggregated quotes are about $\$ 0.31 / \mathrm{W}$ lower than the corresponding direct quotes, on average, for the 1,108 pairs ( Figure 7). The aggregated quote is lower than the corresponding direct quote in about $62 \%$ of pairings. The difference is statistically significant $(\mathrm{t}=11.1)$. Consistent with our hypotheses in Section 2, the paired difference result implies that installers offer lower prices to the same customers when bidding on the quote platform.

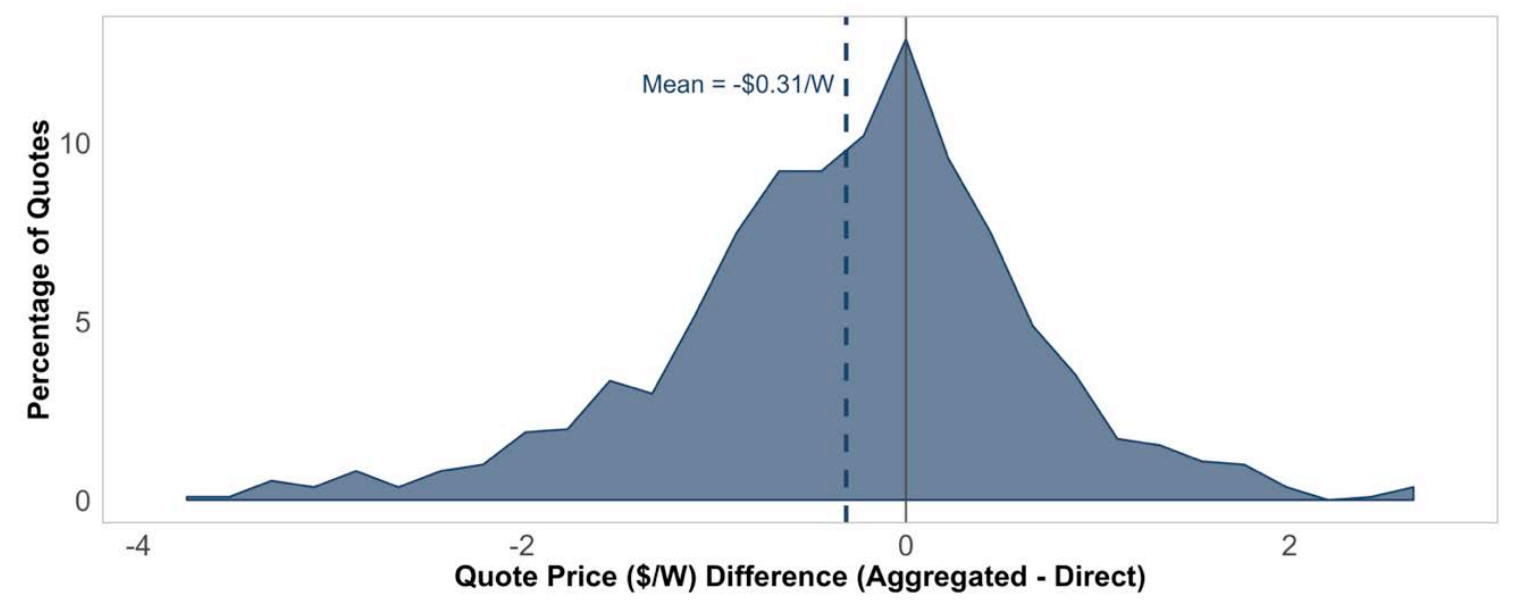

Figure 7. Paired difference distribution

The paired difference test results provide further evidence that installers bid lower prices on the quote platform than when they bid directly to customers. However, at least some of the observed difference may be due to differences in system characteristics. For example, as discussed in Section 4.2, aggregated quotes are less likely to include premium panels than direct quotes. We control for systematic differences that affect prices through the following model:

$$
p_{i}=\beta_{0}+\beta_{1} \text { size }_{i}+\beta_{2} \text { size }_{i}^{2}+\beta_{3} \text { date }_{i}+\beta_{4} \bmod _{i}+\beta_{5} \text { inv }_{i}+\varepsilon_{i}
$$

Where $p_{i}$ is the quote price for quote $i$, size $_{i}$ and $s i z e_{i}^{2}$ are the system size and system size squared, ${ }^{15}$ date $_{i}$ is the quote date, $\bmod _{i}$ is a module fixed effect (economy, standard, or premium), $i n v_{i}$ is an inverter fixed effect (string, micro, or DC optimizer), $\varepsilon_{i}$ is a residual term for quote $i$, and the terms $\beta$ are the coefficients in the model. The residual term $\varepsilon$ is the variation in the quote price that remains after controlling for the other factors in the model. A high residual value indicates the quote is relatively expensive after controlling for these factors, and a low residual value indicates the quote is relatively inexpensive. We use the residual term to create a difference metric that controls for potentially confounding factors.

\footnotetext{
${ }^{15}$ Previous work (Gillingham et al. 2016; Nemet et al. 2017) has identified a quadratic relationship between system size and prices. In other words, larger systems tend to be installed with lower prices, but the effect is weaker for increasingly larger systems.
} 
Aggregated quote prices were about $\$ 0.01 / \mathrm{W}$ lower than predicted by the model, while direct quote prices were about $\$ 0.16 / \mathrm{W}$ higher than predicted by the model, on average. The paired difference in quote prices falls to about $\$ 0.24 / \mathrm{W}$ after controlling for these system characteristics, but it remains statistically significant $(\mathrm{t}=5.0)$ (Figure 8).

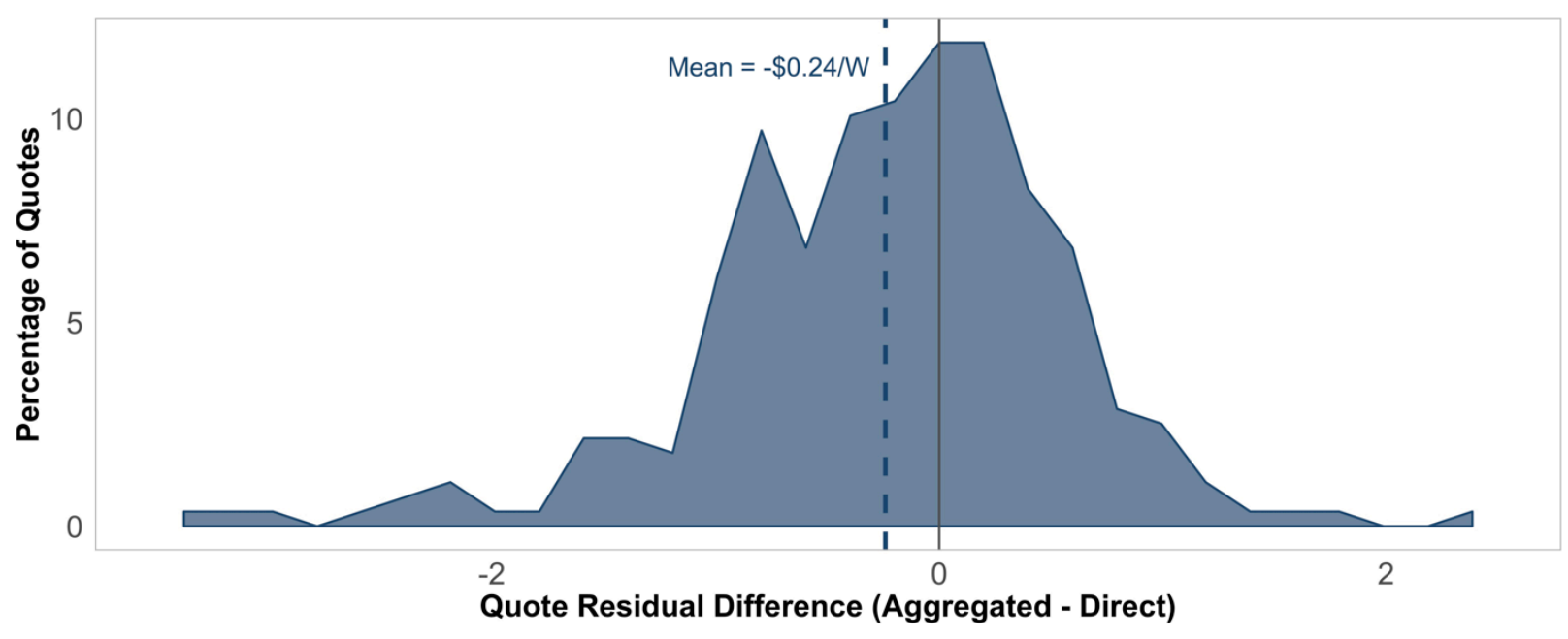

Figure 8. Paired difference distribution of residuals

\subsection{Regression Results}

Table 3 displays the results of several versions of the regression model described in Section 3 , with and without certain fixed effects:

$$
\begin{gathered}
\text { (1) } p=\operatorname{comp} \lambda+X \beta+Q T R+\varepsilon \\
\text { (2) } p=\operatorname{comp} \lambda+X \beta+Q T R+C T Y+\varepsilon \\
\text { (3) } p=\operatorname{comp} \lambda+X \beta+Q T R+I N S T+\varepsilon \\
\text { (4) } p=\operatorname{comp} \lambda+X \beta+Q T R+C T Y+I N S T+\varepsilon
\end{gathered}
$$

The first row (highlighted) in Table 3 (next page) displays the coefficients for expected competition. Because the variable is logged, the coefficients can be interpreted as the effect on average price $(\$ / \mathrm{W})$ from doubling the number of expected rivals.

The first model (1) illustrates the logic of the fixed effects models. In (1), prices are positively correlated with expected competition because of geographic differences. Installed prices are generally higher in California than in other states for a variety of reasons. At the same time, many more installers operate in California than other states. These two facts establish a spurious positive relationship between prices and expected competition. The fixed effects models resolve this issue. The county fixed effects model (2) shows that prices are inversely correlated with expected competition when controlling for geographic differences. This relationship is robust with installer fixed effects (3), and both county and installer fixed effects (4). 
Table 3. Regression Results

$\mathrm{Y}=$ price $(\$ / \mathrm{W})$, t-statistics in parentheses

\begin{tabular}{|c|c|c|c|c|}
\hline & $\begin{array}{l}(1) \\
\text { No FE }\end{array}$ & $\begin{array}{l}(2) \\
\text { County FE }\end{array}$ & $\begin{array}{l}\text { (3) } \\
\text { Installer FE }\end{array}$ & $\begin{array}{l}\text { (4) } \\
\text { County FE, } \\
\text { Installer FE }\end{array}$ \\
\hline $\begin{array}{l}\text { Expected } \\
\text { competition } \\
\text { (logged) }\end{array}$ & $\begin{array}{l}0.058 \\
(16.5)^{a}\end{array}$ & $\begin{array}{l}-0.054 \\
(11.6)^{a}\end{array}$ & $\begin{array}{l}-0.056 \\
(15.1)^{a}\end{array}$ & $\begin{array}{l}-0.065 \\
(15.5)^{\mathrm{a}}\end{array}$ \\
\hline System size (kW) & $\begin{array}{l}-0.03 \\
(52.7)^{a}\end{array}$ & $\begin{array}{l}-0.03 \\
(51.2)^{a}\end{array}$ & $\begin{array}{l}-0.03 \\
(58.7)^{a}\end{array}$ & $\begin{array}{l}-0.03 \\
(55.4)^{\mathrm{a}}\end{array}$ \\
\hline System size ${ }^{2}\left(\mathrm{~kW}^{2}\right)$ & $\begin{array}{l}0.0002 \\
(24.2)^{a}\end{array}$ & $\begin{array}{l}0.0002 \\
(19.3)^{a}\end{array}$ & $\begin{array}{l}0.0002 \\
(22.6)^{a}\end{array}$ & $\begin{array}{l}0.0002 \\
(21.5)^{a}\end{array}$ \\
\hline $\begin{array}{l}\text { Annual home } \\
\text { electric use }\end{array}$ & $\begin{array}{l}-1.4 \mathrm{E}-6 \\
(5.5)^{\mathrm{a}}\end{array}$ & $\begin{array}{l}3.2 \mathrm{E}-6 \\
(13.2)^{\mathrm{a}}\end{array}$ & $\begin{array}{l}3.1 \mathrm{E}-6 \\
(14.3)^{\mathrm{a}}\end{array}$ & $\begin{array}{l}3.1 \mathrm{E}-6 \\
(14.4)^{\mathrm{a}}\end{array}$ \\
\hline Standard panel & $\begin{array}{l}-0.01 \\
(2.0)\end{array}$ & $\begin{array}{l}0.03 \\
(5.3)^{a}\end{array}$ & $\begin{array}{l}-0.01 \\
(0.9)\end{array}$ & $\begin{array}{l}0.02 \\
(2.5)\end{array}$ \\
\hline Premium panel & $\begin{array}{l}0.60 \\
(63.7)^{a}\end{array}$ & $\begin{array}{l}0.64 \\
(72.2)^{a}\end{array}$ & $\begin{array}{l}0.53 \\
(51.1)^{a}\end{array}$ & $\begin{array}{l}0.55 \\
(54.4)^{\mathrm{a}}\end{array}$ \\
\hline DC optimizer & $\begin{array}{l}-0.07 \\
(16.4)^{a}\end{array}$ & $\begin{array}{l}-0.07 \\
(17.8)^{a}\end{array}$ & $\begin{array}{l}-0.12 \\
(24.2)^{a}\end{array}$ & $\begin{array}{l}-0.10 \\
(20.9)^{a}\end{array}$ \\
\hline String inverter & $\begin{array}{l}-0.07 \\
(14.7)^{\mathrm{a}}\end{array}$ & $\begin{array}{l}-0.03 \\
(6.6)^{a}\end{array}$ & $\begin{array}{l}-0.06 \\
(9.9)^{a}\end{array}$ & $\begin{array}{l}-0.05 \\
(8.2)^{a}\end{array}$ \\
\hline QTR & $x$ & $x$ & $x$ & $x$ \\
\hline CTY & & $\mathrm{X}$ & & $x$ \\
\hline INST & & & $x$ & $x$ \\
\hline Intercept & $\begin{array}{l}4.2 \\
(276.2)^{a}\end{array}$ & $\begin{array}{l}4.1 \\
(10.0)^{a}\end{array}$ & $\begin{array}{l}5.1 \\
(80.4)^{a}\end{array}$ & $\begin{array}{l}5.1 \\
(13.7)^{a}\end{array}$ \\
\hline $\mathrm{R}^{2}$ & 0.22 & 0.39 & 0.50 & 0.54 \\
\hline
\end{tabular}

${ }^{\text {a }}$ Statistically significant at $p<0.01$

Model (4) suggests that, all else being equal, installers lower their bid prices by about $\$ 0.07 / \mathrm{W}$ when the number of expected competitors doubles. For instance, an installer bids $\$ 0.07 / \mathrm{W}$ less when bidding against another installer than when bidding alone to a customer, on average. This result is consistent with the Competition Effect Hypothesis (Hypothesis 2); installers appear to offer lower prices when installers expect to compete against other installers. By extension, the result suggests installers tend to offer lower prices when customers obtain more quotes. 
Figure 9 illustrates the competition effect for quotes made in California in Q4 2016. The average quote price falls about $15 \%$ from $\$ 3.97 / \mathrm{W}$ for customers with a single expected bidder to $\$ 3.37 / \mathrm{W}$ for customers with seven expected bidders. The relationship between prices and expected competition in Figure 9 is consistent with the logarithmic form of our regression model. Installers appear to discount prices more significantly when moving from one to two expected competitors ( $7 \%$ reduction) than when moving from two to three expected competitors $(2 \%$ reduction).

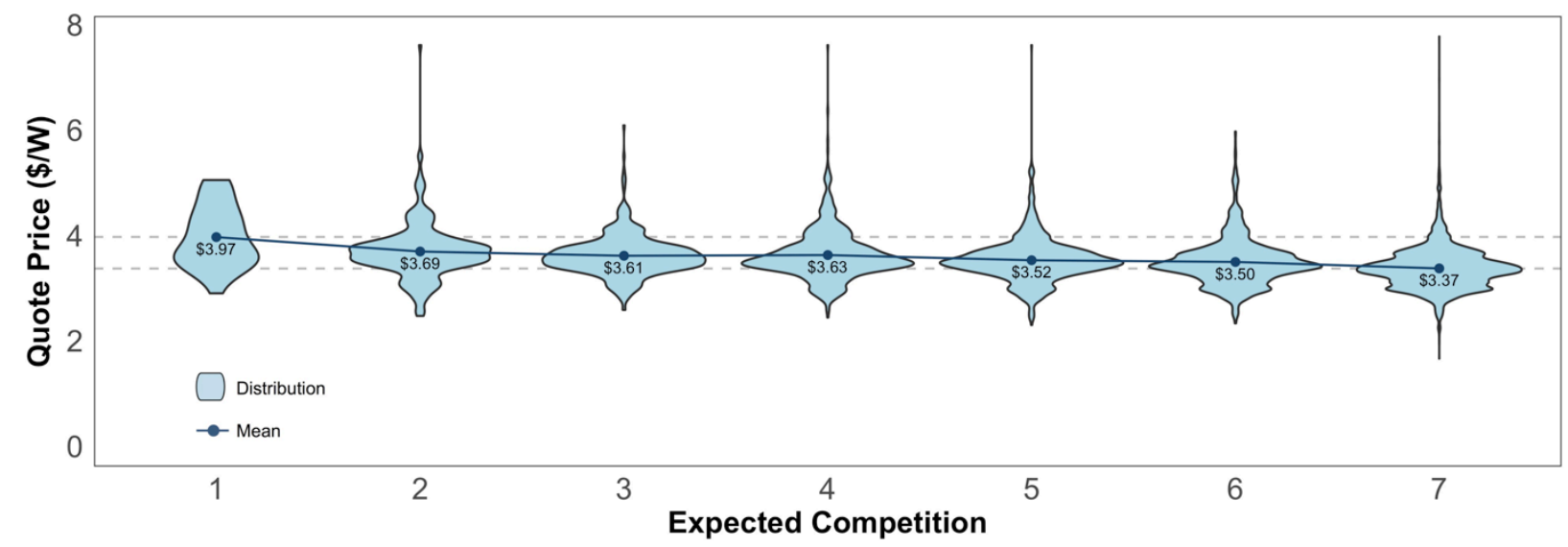

Figure 9. Bid price distributions by expected number of competitors in California, Q4 2016

In nearly every state, customers with seven expected competitors tended to receive lower prices than customers with a single expected competitor (Figure 10). Price differences based on expected competition are particularly significant in Massachusetts, New York, and Washington, D.C. In contrast, bidding patterns in New Jersey and Oregon show the opposite trend; customers with seven expected competitors received higher prices than customers with a single expected competitor, on average. Geographic differences in the effects of market transparency are an area for further research.

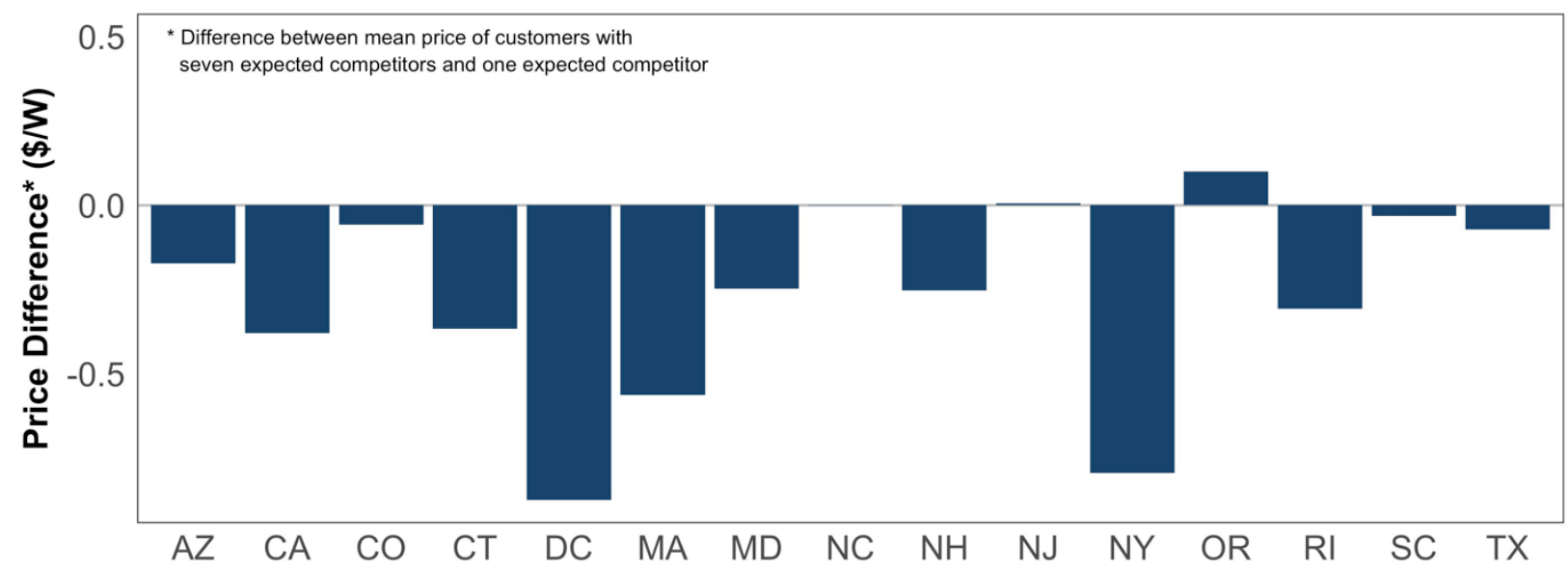

Figure 10. State-level differences between mean price for quotes with seven expected competitors and one expected competitor, 2016 data

Some states are excluded where no customers received seven quotes. 


\section{Installer Survey Results}

The results in Section 4 suggest installers offer lower prices on the quote platform than when bidding directly to customers. Further, the results indicate installers offer lower prices to customers that receive more quotes. These findings are consistent with our hypotheses for the effects of market transparency on prices (see Section 2). To understand the effects of market transparency from the perspective of installers, we interviewed seven installers from the EnergySage installer network (see Acknowledgements for a list of interviewees).

This section provides insights from the installers' perspectives on how market transparency and quote aggregation affect installer bidding behavior. Although the sample is not comprehensive, the anecdotes provide valuable insights from the perspective of installers that can help contextualize the results of our empirical study. We organize these insights into four effects of quote aggregation: 1) effects on prices, 2) effects on equipment choices, 3) effects on customers, and 4) effects on installers.

\subsection{Effects on Prices}

All interviewees (7/7) stated that quote aggregation reduces prices. All interviewees reported that the highly competitive environment on the quote platform forces installers to reduce margins or find ways to cut costs. Several interviewees reported offering lower prices on the quote platform than when bidding directly to customers.

All interviewees (7/7) stated that competition affects prices. All interviewees agreed that installers factored competition into their prices, even if the interviewees themselves did not adjust prices to account for competition. Several interviewees reported knowing the price points of their most frequent rivals and aiming to beat these price points or win customers through superior product offerings.

\subsection{Effects on Equipment Choices}

Most interviewees (4/7) stated that quote aggregation does not affect equipment choices. Installer equipment decisions are generally determined at the company level and do not vary on or off the quote platform. Some interviewees (3/7) offer slightly different packages on the quote platform. For example, one interviewee reported offering a more basic package in their initial offer, given that the platform does not provide fields for some accessory equipment (e.g., squirrel guards).

Most interviewees (5/7) stated that premium equipment is difficult to sell on the quote platform. These interviewees, typically installers of high-efficiency modules, argued that customers require in-person consultations to appreciate the benefits of premium equipment. Several interviewees argued that the challenge of selling premium equipment on the quote platform results in a "race to the bottom," where their competitors typically offer budget lowquality systems that are difficult to compete against without in-person customer contact. However, as noted in Section 4, premium equipment appears to perform relatively well on the quote platform despite these installers' perceptions. One possible explanation for this is that premium equipment performs poorly in initial quotes, but customers develop a preference for premium components after speaking with installers or reading educational materials on the quote aggregator's website. 


\subsection{Effects on Customers}

Interviewees generally reported that two types of customers solicit bids through the quote aggregator. The first type consists of customers that are seriously considering adoption and use the quote aggregator's educational materials to become more informed. The second type consists of customers that are dabbling in PV. Typically, they are not very serious about adoption but use the quote platform to get a sense of prices. In general, installers reported that the first group is more informed than the typical prospective customer base, while the second group is less informed than other customers.

Several interviewees reported that the "seriously considering" PV customers on the quote platform are interested in system value, not only prices. Several interviewees stated that some customers become more informed about system value by using the quote aggregator's educational materials. One installer reported that informed quote platform customers are interested in non-price product attributes such as warranties. Several installers stated that quote platform customers are less susceptible to "hard sales" tactics, which creates a greater level of consumer protection on the platform. According to some interviewees, quote platform customers are more empowered to select the option that works best for them.

Several installers reported that some quote aggregator customers are less informed than other customers. The ease of using an online quote aggregation platform may attract relatively uninterested prospective customers. The quote platform is an easy way for a prospective customer to assess whether PV is a good option before making a more serious commitment to the adoption process. These uninformed customers tend to concentrate on price rather than holistic system value.

Installers had mixed opinions on whether quote aggregation is an effective customer education method. Several interviewees stated that quote platform customers use the educational materials on the quote aggregator's website to become more informed about solar. In addition, with their exposure to multiple quotes, quote platform customers are more knowledgeable about prices. However, according to others, quote aggregation is less effective for customer education than in-person consultations. These interviewees argued that quote aggregation, by removing inperson sales from the equation, may ultimately result in inferior outcomes for customers that are less informed of their options.

\subsection{Effects on Installers}

All interviewees (7/7) stated that quote aggregation reduces installer profit margins. Increased competition on the quote platform forces installers to cut costs or reduce profit margins. All else being equal, lower profit margins reduce the profitability of PV installation companies.

Most interviewees stated that PV demand is higher on the quote platform, but higher demand may not result in more sales. All interviewees agreed that the quote aggregation platform attracts customers to considering PV that may not have otherwise considered, thus increasing demand. At the same time, increased demand does not necessarily equate to increased sales if fewer prospective customers ultimately adopt. Some interviewees argued that customers are more likely to adopt on the quote platform, while other interviewees argued that customers are less likely to adopt on the platform. Interviewees in the latter group argued that quote aggregation 
reduces customer conversion rates by diminishing the role of trained sales professionals. Representatives at EnergySage confirmed that installers with strong online sales capabilities tend to outperform others on the platform that rely more heavily on traditional offline "hard sales" tactics. ${ }^{16}$

Most interviewees stated that quote aggregation reduces per-installer lead conversion rates. As a result of increased competition, installers generally win a smaller percentage of prospective customers on the quote platform than when bidding directly to customers. Only one interviewee stated that their lead conversion rates were comparable on and off the platform.

All installers (7/7) reported that quote aggregation requires a different customer acquisition approach. One interviewee noted that quote aggregation "removes sales from the equation." In other words, in-person salesmanship is largely absent from the quote platform; customers make decisions based on price, system metrics, and online communication. The removal of "sales from the equation" forces installers to develop new approaches for customer acquisition. Several interviewees assign dedicated staff to interface with customers on the quote platform. Representatives of EnergySage affirmed that training and dedicating sales staff to mastering their online platform is recommended as a best practice.

\section{All installers (7/7) reported that quote aggregation affects customer acquisition costs.}

Interviewees generally reported that the quote aggregator's fee is lower than typical customer acquisition costs through other channels. One installer estimated that their costs for direct customer acquisition are about two to three times higher than the quote aggregator's flat fee. However, some interviewees noted that the aggregator's fee is higher than the customer referral fees they offer. One interviewee stated that the aggregator's fee is higher than the cost to acquire leads through trade shows. These responses are consistent with recent research (Mond 2017) showing customer acquisition costs on quote platforms tend to be lower than through door-todoor sales and purchased leads but higher than they are through referrals and events.

\section{Several interviewees (3/7) reported that quote aggregation increases certainty over costs.}

The quote aggregator, at least in the case of EnergySage, charges a transparent flat fee for each completed sale. In contrast, costs for direct customer acquisition are variable and incurred regardless of whether the installer wins the customer. Interviewees stated that the certainty of the quote aggregator's fee improves installer confidence in accounting for customer acquisition costs in their pricing models.

Quote aggregation helps some installers but may hurt others. The effect of quote aggregation on installer profitability depends on the net effect of lower margins, increased demand, and lower lead conversion rates. Some installers reported that quote aggregation improves their profitability, despite lower margins, because of overall increased and more predictable sales volumes. However, most interviewees reported that the quote platform also presented a more challenging competitive environment that may ultimately reduce long-term profitability if not mastered as a new sales channel. According to these interviewees, installers would need to make

\footnotetext{
${ }^{16}$ Similar dynamics are occurring in other markets converting from in-person to online sales. See for example the auto sales industry (Rogers 2013).
} 
significant changes to their business models to remain viable if quote aggregation platforms became more common.

\subsection{Installer Survey Summary}

Table 4 summarizes the reported effects of quote aggregation from the installer interviews. Interview responses for the effects of quote aggregation on prices are consistent with the results of our empirical study. Interviewee responses for the effects of quote aggregation on equipment, customers, and installers reveal additional nuances in the effects of market transparency. Interviewees generally agreed quote aggregation had little impact on equipment choices but made selling premium equipment more difficult. While installers generally agreed quote platform customers are more informed than other customers, several interviewees also noted how some quote platform customers are less serious about PV adoption and less informed. Further, installers noted that quote aggregation and market transparency could have a number of impacts on PV installers. All interviewees agreed quote aggregation results in lower margins and generally lower lead conversion rates because of increased competition. Some installers could benefit from quote aggregation because of increased access to more customers; however, other interviewees noted that large-scale quote aggregation would reduce their company's profitability.

Table 4. Interview Summary: Effects of Quote Aggregation

\begin{tabular}{ll}
\hline Prices & - More competition \\
& - Lower prices \\
Equipment & - Little effect on equipment choices \\
& - Some installers lead with more basic packages. \\
& - Some installers have difficulty selling premium equipment. \\
Customers & equipment... \\
& - $\ldots$ but others are less serious about adoption and less informed. \\
& - Less profitable \\
& - Lower lead conversion rate because of increased competition \\
- Higher sales as a result of increased demand if new sales channel is mastered \\
& - Increased certainty about customer acquisition cost \\
& - Quote aggregation helps some installers but hurts others
\end{tabular}




\section{Discussion and Conclusion}

PV markets are relatively non-transparent. Installers have little incentive to advertise prices, as doing so reduces bargaining power during contract negotiations. Further, prospective customers are mostly unfamiliar with the new technology and PV is an infrequent purchase, making it difficult for customers to become market savvy through repeat purchasing. Low PV market transparency results in some customers receiving higher quote prices and may ultimately reduce PV adoption. However, other analogous industries, such as roofing have markets that are arguably more transparent than PV markets because of customer experience and the availability of customer-facing tools, such as price guides and cost calculators. Quote aggregation-where third-party companies connect customers with multiple installers - may be one means to increase PV market transparency.

We use residential quote data from a PV quote aggregator to explore the effects of quote aggregation on market transparency, prices, and product choice. We find that quote aggregation drives installers to offer lower prices primarily because of increased competition. Specifically, we find, after controlling for system characteristics, PV installers bid $\$ 0.24 / \mathrm{W}$ lower on the aggregator's quote platform than when they bid directly to customers, on average. Further, we find that installers tend to reduce quote prices by about $\$ 0.07 / \mathrm{W}$ for each doubling of the number of expected competitors for any given customer. The data suggest customers that receive seven quotes may save as much as $\$ 0.48 / \mathrm{W}$ more than customers that receive a single quote. For a typical 5-kW system, this delta could translate into roughly $\$ 2,500$ in savings.

Our results support our two hypotheses:

- The Informed Customer Effect: Economic theory suggests that more-informed customers obtain lower prices and superior product quality. Quote aggregation may result in more-informed customers with increased access to quotes and product quality information on the quote platform. Interviewees generally agreed that quote platform customers are more informed than other customers, though the platform may also attract a group of dabblers, who are generally less informed and less serious about purchasing PV. Interviewees also reported that informed customers are less susceptible to hard sales tactics, suggesting that quote aggregation fosters increased consumer protection. Our results support our hypothesis that more-informed customers obtain lower prices. We do not find evidence that customers obtain different products on the quote platform.

- The Competition Effect: All being else equal, economic theory suggests that installers should offer lower prices when customers receive more quotes. Our regression model shows that installers tend to bid lower prices when expecting to compete against more installers. This empirical result is corroborated by the fact that all interviewees in our installer survey agreed quote aggregation results in a more competitive bidding environment that drives down prices. 
Our results support our hypothesis that market transparency via quote aggregation results in lower PV prices. We find that installers are less likely to offer premium panels on the quote platform than they do through direct quotes, although premium panels appear to perform relatively well on the platform (in terms of finalized sales). Installers offer lower prices on the quote aggregation platform for all system types, which suggests that quote aggregation increases system value even if aggregation does not induce installers to offer more premium panels. The effects of quote aggregation on installer equipment choices are an area for further research.

These results have several policy implications. First, our results indicate that policies to improve market transparency may be an effective avenue for further PV price reductions. Second, the empirical results and the installer interviews show the importance of program design. Quote platform designers must be cognizant of a potential "race to the bottom," where customers and installers focus only on price while ignoring system quality. Third, our results further validate the importance of healthy competition for the PV industry. We find clear evidence that installers offer lower prices when customers obtain more quotes.

There are a number of future research directions to build on our work. First, our results show that market transparency and quote aggregation may have different impacts in different markets. Future work could explore why and how the effects of market transparency vary geographically. Second, responses from the installer interviews prompt many additional questions, such as the following: Are quote aggregation customers more informed? What is the role of professional salespeople in more transparent PV markets? And, how does transparency affect PV installers? Last, future research could explore program design for market transparency programs to ensure optimal outcomes that ensure competitive environments with low prices and high product quality. 


\section{References}

Akerlof, G. 1970. "The Market for 'Lemons': Quality Uncertainty and the Market Mechanism.” The Quarterly Journal of Economics 84(3): 488-500.

Ahmad, I., and I. Minkarah. 1988. "Questionnaire Survey on Bidding in Construction.” Journal of Management in Engineering. 4(3):229-243.

Anderson, S., and R. Renault. 2006. “Advertising Content.” The American Economic Review 96(1): 93-113.

Barbose, G., and N. Darghouth. 2016. Tracking the Sun VIII: The Installed Price of Residential and Non-Residential Photovoltaic Systems in the United States. Berkeley, CA: Lawrence Berkeley National Laboratory.

Baye, M.R., J. Morgan, and P. Scholten. 2003. "The Value of Information in an Online Consumer Electronics Market.” Journal of Public Policy \& Marketing 22(1):17-25.

Boone, J., and J. Pottersz. 2006. "Transparency and Prices with Imperfect Substitutes." Economics Letters 93: 398-404.

Brynjolfsson, E., and M. Smith. 2000. "Frictionless Commerce? A Comparison of Internet and Conventional Retailers." Management Science 46(4): 563-585.

Carr, R. "Impact of Number of Bidders on Competition." Journal of Construction Engineering and Management 109(1): 61-73.

EnergySage. 2017. Solar Installer Survey 2016 Results.

Gillingham, K., H. Deng, R.H. Wiser, N. Darghouth, G. Nemet, G.L. Barbose, V. Rai, and C. Dong. 2016. "Deconstructing Solar Photovoltaic Pricing: The Role of Market Structure, Technology, and Policy." The Energy Journal 37(3): 231-250.

Gu, Y., and T. Wenzel. 2011. "Transparency, Price-Dependent Demand and Product Variety." Economics Letters 110: 216-219.

Hart, O., and J. Moore. 1988. "Incomplete Contracts and Renegotiation.” Econometrica 56(4): $755-785$.

Hoppe, E., and P. Schmitz. 2011. "Can Contracts Solve the Hold-Up Problem? Experimental Evidence." Games and Economic Behavior 73: 186-199.

Levin, D., and J. Smith. 2004. "Equilibrium in Auctions with Entry." The American Economic Review 84: 585-599.

Litvak, N. 2017. U.S. Residential Solar Update 2017. GTM Research.

Lorentziadis, P. 2016. "Optimal Bidding in Auctions from a Game Theory Perspective." European Journal of Operational Research 248: 347-371.

McAfee, R.P., and J. McMillan. 1987. "Auctions and Bidding." Journal of Economic Literature 25(2): 699-738.

Mochtar, K., and D. Arditi. 2001. "Pricing Strategy in the US Construction Industry." Construction Management and Economics 19:405-415. 
Moezzi, M., A. Ingle, L. Lutzenhiser, and B. Sigrin. 2017. A Non-Modeling Exploration of Residential Solar Photovoltaic Adoption and Non-Adoption. Golden, CO: National Renewable Energy Laboratory. NREL/SR-6A20-67727.

Mond, A. 2017. U.S. Residential Solar PV Customer Acquisition 2017. GTM Research.

Nemet, G., E. O'Shaughnessy, N.R. Darghouth, R.H. Wiser, G.L. Barbose, K. Gillingham, and V. Rai. 2017. Sources of Price Dispersion in U.S. Residential Solar Installations. Berkeley, CA: Lawrence Berkeley National Laboratory.

Noldeke, G., and K. Schmidt. 1995. "Option Contracts and Renegotiation: A Solution to the Hold-Up Problem." The RAND Journal of Economics 26(2): 163-179.

O’Shaughnessy, E., and R. Margolis. 2017. Using Residential Solar PV Quote Data to Analyze the Relationship between Installer Pricing and Firm Size. Golden, CO: National Renewable Energy Laboratory. NREL/TP-6A20-68010.

Riley, J., and W. Samuelson. 1981. "Optimal Auctions.” The American Economic Review 71: 381-392.

Rogers, C. 2013. "Say Goodbye to the Car Salesman." Wall Street Journal.

Rogerson, W. 1992. "Contractual Solutions to the Hold-Up Problem." The Review of Economic Studies 59(4): 777-793.

Rothkopf, M., and R. Harstad. 1994. "Modeling Competitive Bidding: A Critical Essay." Management Science 40: 364-384.

Salop, S., and J. Stiglitz. 1977. "Bargains and Ripoffs: A Model of Monopolistically Competitive Price Dispersion." The Review of Economic Studies 44(3): 493-510.

Schultz, C. 2009. "Transparency and Product Variety.” Economics Letters 102: 165-168.

Seel, J., G. Barbose, and R. Wiser. 2014. "An Analysis of Residential PV System Price Differences between the United States and Germany." Energy Policy 69: 216-226.

Soh, C., M.L. Markus, and K.H. Goh. 2006. "Electronic Marketplaces and Price Transparency: Strategy, Information Technology, and Success." MIS Quarterly 30(3): 705-723.

Stigler, G. 1961. "The Economics of Information.” Journal of Political Economy 69(3): 213225 .

Tirole, J. 1988. The Theory of Industrial Organization. Cambridge, MA: The MIT Press.

Varian, H. 1980. “A Model of Sales.” The American Economic Review 70(4): 651-659.

Zhang, X., and B. Jiang. 2014. "Increasing Price Transparency: Implications of Consumer Price Posting for Consumers' Haggling Behavior and a Seller's Pricing Strategies." Journal of Interactive Marketing 28: 68-85. 